\title{
Ecological and silvicultural indicatory value of plant-communities of Koto forest reserve (Centre-Benin)
}

\author{
Justin Coffi NOUMON ${ }^{1}$, Jean Cossi GANGLO ${ }^{1^{*}}$, Anastase AZONTONDE ${ }^{2}$, \\ Bruno de FOUCAULT ${ }^{3}$ and Victor ADJAKIDJÈ ${ }^{4}$ \\ ${ }^{1}$ Université d'Abomey-Calavi, Faculté des Sciences Agronomiques, Département d'Aménagement et Gestion \\ de l'Environnement, 01 BP 526, Cotonou, République du Bénin. \\ ${ }^{2}$ Institut national des recherches agricoles du Bénin, 01 BP 884 Recette Principale, \\ Cotonou, République du Bénin. \\ ${ }^{3}$ Départment of Botany, Faculty of pharmaceutic and biological Sciences, BP 83, F-59006 Lille Cedex; \\ phone 00333209640 40; fax: 00333209590 09; mail: bdefouca@pharma.univ-lille2.fr \\ ${ }^{4}$ Faculté des Sciences et Techniques, 01 BP 526, Cotonou, République du Bénin. \\ * Corresponding author, Tél: 00229213601 26; 00229210820 31; \\ Fax: 00229213601 22; E-mail: ganglocj@yahoo.fr
}

\begin{abstract}
A study was carried out in Koto forest reserve in central Benin $\left(6^{\circ} 56^{\prime}\right.$ to $7^{\circ} 02^{\prime}$ of north lat. and $02^{\circ} 03^{\prime}$ to $02^{\circ} 09^{\prime}$ of east long), in order to contribute to the sustainable management of the forest. Phytosociological inventory was done using the synusial approach. Soils were studied through texture surveys, pedological profiles description and laboratory analysis. Silvicultural parameters of plantations were studied using temporary sample plots of $300 \mathrm{~m}^{2}$. The study helps to identify and describe twenty-two basic plantcommunities named synusia. Based on their relationships, the synusia have been combined to describe seven phytocoenoses (plant-communities). Each non pioneer phytocoenose is an expression of specific ecological conditions. The study of plantation productivity has shown remarkable homogeneity of productivity level within each non pioneer phytocoenose. Analysis of variance reveals a significant difference at $5 \%$ of probability level between the productivity levels of the phytocoenoses. Three productivity levels are identified according to phytocoenoses. The study leads to the conclusion that phytosociology is a reliable tool for forest management.

(C) 2009 International Formulae Group. All rights reserved.
\end{abstract}

Keywords: Phytosociology, synusial approach, phytocoenose, productivity.

\section{INTRODUCTION}

Deforestation and fragmentation of the world forests continue at alarming rates, resulting in serious problems including irreversible loss of genetic resources. As a proof of this, FAO (2005) reported an annual deforestation rate of 7.3 million hectares of the world forests between 2000 and 2005.

Benin Republic has limited forest resources. FAO (2005) reported that Benin has about 2351000 ha of natural forests and forest plantations. Unfortunately, the forest resources are subjected to rapid depletion because of seasonal fires, intensive grazing and extensive agriculture. In Benin, in order to supply the needs of populations in forest products, forest plantations have been carried out since the 1940s. To provide populations with sustainable forest resources, it is important to take into account forest research results. However, sound forest research results to guide silviculture are badly lacking in our 
country (Ganglo and Maître, 2003). One of the key factors that enable efficient silviculture is a clear knowledge of forest sites, in terms of their constraints and potentialities. In a classical way, the identification, characterisation and mapping of forest sites are time and resource consuming. Indeed, to achieve this, it is indispensable to study geology, soils, topography, microclimate..., vegetation and their relationships in order to derive homogenous forest spaces in term of ecological and biological factors (Sabatier, 2006). The introduction of phytosociology in vegetation analysis some years ago (Braun-Blanquet, 1932; Lebrun, 1947; Guinochet, 1955; Pignatti et al., 1995) helps to understand that plant communities are a synthesis of the interaction of ecological factors. Furthermore, recent research results in the undergrowth vegetation of forest plantations enable to understand the homogeneity of ecological factors, mainly soil and topography, in the biotopes of non pioneer undergrowth plant communities (Ganglo, 2005; Noumon and Ganglo, 2005; Aoudji and Ganglo, 2006; Ganglo and De Foucault, 2006). Phytosociology comes out then to be a very useful tool for a less time and resource consuming approach to identify and characterise forest sites. We successfully used this approach in the forest plantations of Koto forest reserve and the purpose of this article is to present the main results achieved.

\section{MATERIALS AND METHODS Study area}

Koto forest reserve is located in Central Benin $\left(6^{\circ} 56^{\prime}\right.$ to $7^{\circ} 02^{\prime}$ ' of north lat. and $02^{\circ} 03^{\prime}$ to $02^{\circ} 09^{\prime}$ of east long) at the northwestern part of Lama Forest reserve (Figure 1). This forest is submitted to a subequatorial climate, with a long rainy season from March to July and a short rainy season from September to October. The long dry season extends from November to February and the short dry one covers August. The mean annual rainfall observed from 1987 to 2006 is 1,153 $\mathrm{mm}$. During the same period the mean daily temperature is about $28{ }^{\circ} \mathrm{C}$ while relative humidity varied from $40 \%$ to $98 \%$.
Two major types of soils occurred in the forest (Viennot, 1966): typical black cotton soils and sandy soils.

$>$ Black cotton soils are dark in the upper horizons. In the rainy season, they are similar to muddy soils because of ill drainage. The soils have very slow hydraulic conductivity when moist and have high bulk density when dry. Clay is dominant in their profiles (46$63 \%$ ); the organic matter content is from $2 \%$ to $4 \%$; the $\mathrm{C} / \mathrm{N}$ ratio varies from 10 to 13 ; the $\mathrm{pH}$ extends from 5 to 6 whereas the cationic exchange capacity varies from $28-30 \mathrm{meq} / 100$ $\mathrm{g}$ with a saturation rate of $74 \%$ to $99 \%$. This is the major soils found in Koto forest and, support $80 \%$ of the plantations;

$>$ Sandy soils are found in the north eastern part of the forest and mainly cover plots 3 and 4 (Figure 1). These soils are light in the upper horizons and dark in depth. In the upper horizons, sand is dominant (84\%); the soil $\mathrm{pH}$ is around 6 whereas the organic matter content is very low (1\%); the $\mathrm{C} / \mathrm{N}$ ratio is around 11 ; the cationic exchange capacity is low and varies from 2 to $5 \mathrm{meq} / 100 \mathrm{~g}$ of soil and the saturation rate is from $53 \%$ to $63 \%$.

The natural vegetation of Lama is a semi-deciduous forest, periodically flooded in rainy season (Paradis and Houngnon, 1977). The most common species of the forest are Diospyros mespiliformis, Dialium guineense, Mimusops andongensis and Afzelia africana.

Figure 1 (position)

Koto forest reserve is actually covered by 2,541 ha of forest plantations where Teak is dominant ( $86 \%$ of the forest area); the other species are Terminalia superba, Gmelina arborea, Khaya senegalensis and Afzelia africana.

\section{Phytosociological study of the spontaneous vegetation}

In the study of the spontaneous vegetation of the forest plantations of Koto forest reserve, we used the synusial approach to phytosociology developed by Gillet et al. (1991) and Gillet (2000). To achieve this study we used a forest map 1/10,000 scale and Sunnto compass for orientation on the field and phytocoenose mapping; a global positioning system (GPS) is used to record relevant points and phytocoenose contours. 


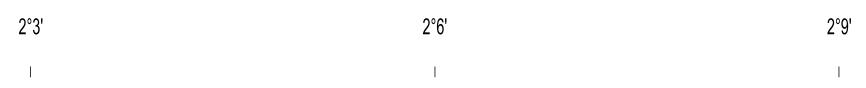

$7^{70} \bar{p}^{-}$

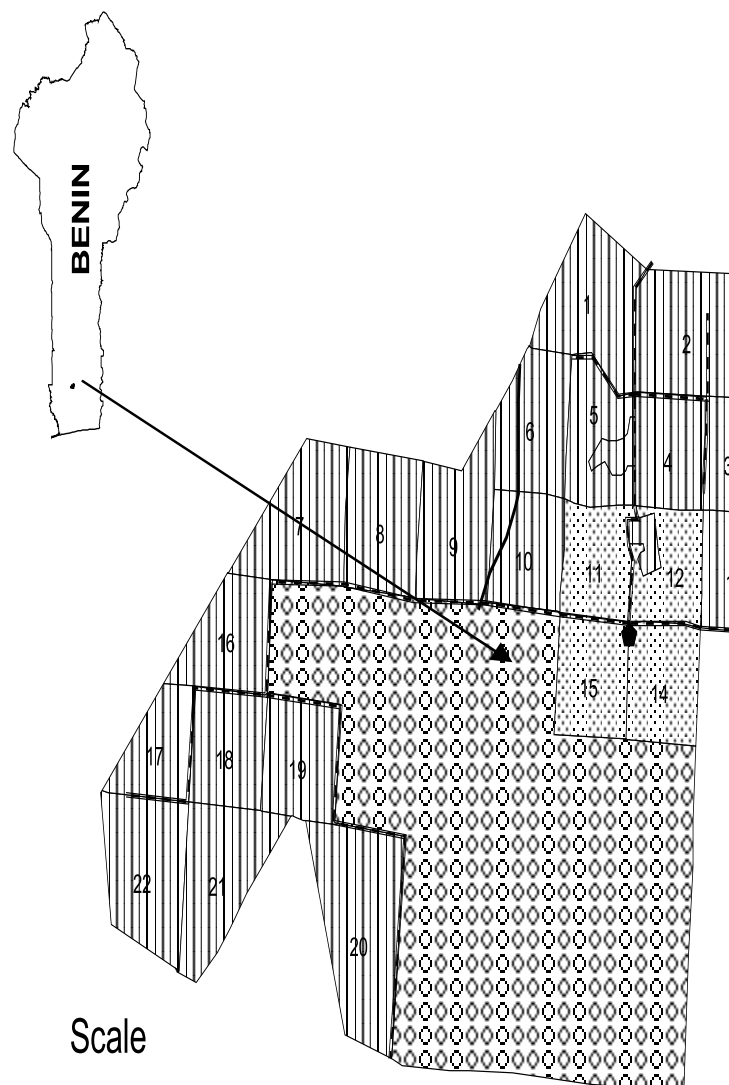

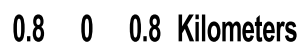

Akpè forest

\section{Legend}

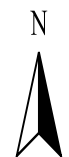

635
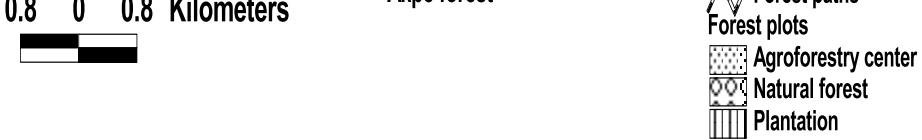

- Secteur

Water way

Forest paths orest plots

Natural forest

IIII Plantation

Figure 1: Koto forest reserve.

In the study of the spontaneous vegetation, we use the synusial approach to phytosociology developed by Gillet et al. (1991) and Gillet (2000). We have distinguished the following categories of synusia (basic plant-community): annual synusia, low perennial-herbaceous synusia, high perennial-herbaceous synusia, shrubby synusia, liana-synusia and tree-synusia. The surface of relevés varies from $500 \mathrm{~m}^{2}$ in the annual and herbaceous synusia to $1000 \mathrm{~m}^{2}$ in the other ones. In each relevé, all the flowering species are recorded. Based on spatial and temporal relationships, the 
Table 1: Phytocoenose diversity and ecological indicatory values.

\begin{tabular}{|c|c|c|}
\hline Phytocoenose & Synusia components & Ecological indicatory values \\
\hline $\begin{array}{l}\text { Chromolaena } \\
\text { odorata- } \\
\text { Panicum } \\
\text { maximum } \\
\text { phytocoenose }\end{array}$ & $\begin{array}{l}\text { Chromolaena odorata - Panicum } \\
\text { maximum high perennial-herbaceous } \\
\text { synusia, Phyllanthus amarus - } \\
\text { Aneilema beniniense annual synusia, } \\
\text { Crinum jagus - Chlorophytum } \\
\text { blepharophyllum low perennial- } \\
\text { herbaceous synusia, Cissus rufescens } \\
\text { - Chlorophytum blepharophyllum low } \\
\text { perennial-herbaceous synusia }\end{array}$ & $\begin{array}{l}\text { Mesophile site with direct sunlight, } \\
\text { irrespective of types of soils and topography. }\end{array}$ \\
\hline $\begin{array}{l}\text { Mallotus } \\
\text { oppositifolius - } \\
\text { Deinbollia } \\
\text { pinnata } \\
\text { phytocoenose }\end{array}$ & $\begin{array}{l}\text { Mallotus oppositifolius - Deinbollia } \\
\text { pinnata } \text { shrubby synusia, Gloriosa } \\
\text { superba-Asystasia gangetica annual } \\
\text { synusia, Crinum jagus - } \\
\text { Chlorophytum blepharophyllum low } \\
\text { perennial-herbaceous synusia, Cissus } \\
\text { rufescens - Anchomanes difformis } \\
\text { high perennial-herbaceous synusia, } \\
\text { Ceiba pentandra tree synusia }\end{array}$ & $\begin{array}{l}\text { Mesophile site on well drained black cotton } \\
\text { soils, usually found at the top of slopes or } \\
\text { moderate slopes; } 46-63 \% \text { of clay in the upper } \\
\text { soil horizons; } 2-4 \% \text { of organic matter; } \mathrm{C} / \mathrm{N} \\
\text { ratio }=10-13 ; \mathrm{pH}=5.4-6.1 ; \text { cationic } \\
\text { exchangeable capacity }=28-30 \text { meq } / 100 \mathrm{~g} \text { of } \\
\text { soil in the upper horizon. }\end{array}$ \\
\hline $\begin{array}{l}\text { Paullinia pinnata } \\
\text { - Reissantia } \\
\text { indica } \\
\text { phytocoenose }\end{array}$ & $\begin{array}{l}\text { Paullinia pinnata - Reissantia indica } \\
\text { liana synusia, Phyllanthus amarus - } \\
\text { Physalis angulata annual synusia, } \\
\text { Cissus rufescens - Chlorophytum } \\
\text { blepharophyllum low perennial- } \\
\text { herbaceous synuisa, Phaulopsis } \\
\text { falcisepala hygrophile low perennial- } \\
\text { herbaceous synusia and Acacia caffra } \\
\text { tree synusia }\end{array}$ & $\begin{array}{l}\text { Mesophile site on poorly drained black cotton } \\
\text { soils, usually found on weak to moderate } \\
\text { slopes; } 45-56 \% \text { of clay in the upper soil } \\
\text { horizons; } 1-3 \% \text { of organic matter; } \mathrm{C} / \mathrm{N} \text { ratio } \\
\text { around } 13 ; \mathrm{pH}=5.7-6.1 ; \text { cationic } \\
\text { exchangeable capacity }=28-34 \mathrm{meq} / 100 \mathrm{~g} \text { of } \\
\text { soil in the upper horizon. }\end{array}$ \\
\hline $\begin{array}{l}\text { Uvaria chamae- } \\
\text { Macrosphyra } \\
\text { longistyla } \\
\text { phytocoenose }\end{array}$ & $\begin{array}{l}\text { Uvaria chamae - Macrosphyra } \\
\text { longistyla } \text { shrubby synusia, } \\
\text { Sansevieria liberica - Anchomanes } \\
\text { difformis low perennial-herbaceous } \\
\text { synusia, Cissus rufescens - } \\
\text { Anchomanes difformis high perennial- } \\
\text { herbaceous synusia and Ceiba } \\
\text { pentandra tree synusia }\end{array}$ & $\begin{array}{l}\text { Mesophile site on deep ferrallitic soils, usually } \\
\text { found on weak to moderate slopes surrounding } \\
\text { plateaux; } 80-83 \% \text { of sand in the upper soil } \\
\text { horizons; } 1-2 \% \text { of organic matter; } \mathrm{C} / \mathrm{N} \text { ratio } \\
\text { around } 11 ; \mathrm{pH}=6.6-7.1 ; \text { cationic } \\
\text { exchangeable capacity }=4-6 \text { meq } / 100 \mathrm{~g} \text { of soil } \\
\text { in the upper horizon. }\end{array}$ \\
\hline $\begin{array}{l}\text { Andropogon } \\
\text { tectorum - } \\
\text { Imperata } \\
\text { cylindrica } \\
\text { phytocoenose }\end{array}$ & $\begin{array}{l}\text { Andropogon tectorum - Imperata } \\
\text { cylindrica high perennial-herbaceous } \\
\text { synusia, Phyllanthus amarus - } \\
\text { Aneilema beniniense annual synusia, } \\
\text { Crinum jagus - Curculigo pilosa low } \\
\text { perennial-herbaceous synusia, } \\
\text { Sterospermum kunthianum - } \\
\text { Pilostigma thonninghii synusia and } \\
\text { Acacia caffra tree synusia }\end{array}$ & $\begin{array}{l}\text { Dry and degraded areas with black cotton soils } \\
\text { ( } 34-51 \% \text { of clay in the upper horizons) or } \\
\text { sandy soils with low water retention capacity } \\
\text { ( } 39-65 \% \text { of fine sand in the upper soil } \\
\text { horizons); } 0.5-2 \% \text { of organic matter; } \mathrm{C} / \mathrm{N} \text { ratio } \\
=10-11 \% ; \mathrm{pH}=5.7-6.1 ; \text { cationic } \\
\text { exchangeable capacity very low on sand soil } \\
\text { ( } 2-5 \text { meq } / 100 \mathrm{~g} \text { ) and around } 40 \mathrm{meq} / 100 \mathrm{~g} \text { of } \\
\text { soil in the upper horizon. }\end{array}$ \\
\hline $\begin{array}{l}\text { Dialium } \\
\text { guineense- } \\
\text { Diospyros } \\
\text { mespiliformis } \\
\text { phytocoenose }\end{array}$ & $\begin{array}{l}\text { Dialium guineense - Diospyros } \\
\text { mespiliformis tree synusia Crinum } \\
\text { jagus - Curculigo pilosa low } \\
\text { perennial-herbaceous synusia and } \\
\text { Memecylon memecyloides - Celtis } \\
\text { brownii shrubby synusia }\end{array}$ & $\begin{array}{l}\text { Mesophile site on clayey soils, usually found } \\
\text { on weak to moderate slopes in natural forest. }\end{array}$ \\
\hline $\begin{array}{l}\text { Nauclea latifolia } \\
\text { - Mitragyna } \\
\text { inermis } \\
\text { hygrophile } \\
\text { phytocoenose }\end{array}$ & $\begin{array}{l}\text { Nauclea latifolia - Mitragyna inermis } \\
\text { shrubby synusia, Panicum laxum-- } \\
\text { Ludwigia abyssinica low perennial- } \\
\text { herbaceous synusia and Leersia } \\
\text { hexandra - Cyperus distans low } \\
\text { perennial-herbaceous synusia }\end{array}$ & $\begin{array}{l}\text { Hygrophile site with muddy soils periodically } \\
\text { flooded by water. }\end{array}$ \\
\hline
\end{tabular}


Table 2: Variation of plantation productivity (top height of any teak plantation at 25 year-old (Ganglo et al., 1999)) within phytocoenoses.

\begin{tabular}{|c|c|c|c|c|}
\hline $\begin{array}{c}\text { Replication } \\
\text { number }\end{array}$ & $\begin{array}{l}\text { Mallotus. } \\
\text { oppositifolius - } \\
\text { D. pinnata } \\
\text { phytocoenose } \\
\text { (m) }\end{array}$ & $\begin{array}{c}\text { Paullinia pinnata - } \\
\text { Reissantia } \\
\text { Indica } \\
\text { phytocoenose } \\
\text { (m) }\end{array}$ & $\begin{array}{c}\text { Uvaria chamae - } \\
\text { Macrosphyra } \\
\text { longistyla } \\
\text { phytocoenose } \\
\text { (m) }\end{array}$ & $\begin{array}{c}\text { Andropogon } \\
\text { tectorum - } \\
\text { Imperata } \\
\text { cylindrica } \\
\text { Phytocoenose } \\
\text { (m) } \\
\end{array}$ \\
\hline 1 & 30.49 & 27.35 & 28.64 & 16.63 \\
\hline 2 & 30.37 & 28.68 & 25.6 & 15.16 \\
\hline 3 & 31.94 & 27 & 26.35 & 17.78 \\
\hline 4 & 29.28 & 26.39 & 24.29 & 16.6 \\
\hline 5 & 29.64 & 27.6 & 27.01 & 18.14 \\
\hline $\begin{array}{l}\text { Mean index } \\
\text { (m) }\end{array}$ & $30.34 \pm 1.02$ & $27.40 \pm 0.84$ & $26.38 \pm 1.62$ & $16.86 \pm 1.17$ \\
\hline $\begin{array}{l}\text { Amplitude of } \\
\text { productivity } \\
\text { indices (m) }\end{array}$ & 2.66 & 2.29 & 4.34 & 2.98 \\
\hline $\begin{array}{l}\text { Standard } \\
\text { deviation (m) }\end{array}$ & 1.02 & 0.84 & 1.62 & 1.17 \\
\hline $\begin{array}{l}\text { Variation } \\
\text { coefficient } \\
(\%)\end{array}$ & 3.36 & 3.06 & 6.14 & 6.93 \\
\hline
\end{tabular}

Tabulated values are Mean \pm SD of "5" determinations.

Table 3: Variance analysis of the plantation productivity levels according to phytocoenoses.

\begin{tabular}{lcccc}
\hline & Degree of freedom & Mean square & F & P \\
\hline Factors & 3 & 170.3657 & 118.3352 & 0.00001 \\
Error & 16 & 1.439687 & - & \\
total & 19 & 171.805387 & - & \\
The level of significance of the variance analysis in table 3 is $0.001 \%$. &
\end{tabular}

Table 4: Results of the mean test comparison of Newman-Keuls.

\begin{tabular}{lcccc}
\hline & $(\mathbf{1})$ & $\mathbf{( 2 )}$ & $\mathbf{( 3 )}$ & $\mathbf{( 4 )}$ \\
\hline Mean index (m) & 16.86200 & 30.34400 & 27.40400 & 26.37800 \\
And (1) & - & 0.000185 & 0.000168 & 0.000159 \\
Mall (2) & & - & 0.001482 & 0.000371 \\
Paul (3) & & & - & 0.195308 \\
Uva (4) & & & & -
\end{tabular}

The level of significance of the mean test comparison in table 4 is 5\%.In table 4, (And) stands for Andropogon tectorum - Imperata cylindrica-community, (Mall) stands for Mallotus oppositifolius - Deinbollia pinnatacommunity, (Paul) stands for Paullinia pinnata - Reissantia indica-community, (Uva) stands for Uvaria chamaeMacrosphyra longistyla-community.

vegetable synusia are combined to describe phytocoenoses. Each relevé of phytocoenose covers about 6 ha; a total of 58 relevés of phytocoenoses have been assessed, making about $13 \%$ of the total area of the forest plantations of Koto. We distinguish the same types of phytocoenoses as of synusia but the spontaneous tree-phytocoenoses are not present in the plantations.

The plant species identification has been done on the basis of Flora of West Africa (Hutchinson and Dalziel 1954-1972). The names of taxa are derived from Lebrun and Stork (1991-1997). 


\section{Ecological factor and forest plantations parameter study}

The study of soils and topography has been done according to Ganglo and De Foucault (2006). The measurement of dendrometric parameters (diameter and height) has been done by means of tape measure and Blum-Leiss (dendrometer). The dendrometric parameters are studied in representative parts of each phytocoenose. Therefore at least, four rectangular sample plots of $300 \mathrm{~m}^{2}(15 \mathrm{~m} \times 20 \mathrm{~m})$ are assessed in each phytocoenose so that the following parameters are recorded: diameter at breast height $(1.30 \mathrm{~m})$; the height of the two largest trees are measured in each plot in order to calculate top height. Productivity is estimated by using the site index curves elaborated for Teak plantations of south and centre Benin by Ganglo et al. (1999). Productivity indices (Table 2) correspond to the top height of any plantation at 25 year-old. That age is considered as a reference age in the Teak plantations of Benin (Ganglo et al., 1999). In order to compare plantation productivity according to phytocoenoses, we performed variance analysis and applied the mean test comparison of Newman-Keuls at 5\% of probability level; to analyse the scope of variation of the mean indices, we calculated the following parameters: standard deviation of the productivity indices; variation coefficients and, the amplitude of plantation productivity indices. In the comparison, we didn't consider pioneer phytocoenoses such as Chromolaena odorata - Panicum maximum phytocoenoses because their distribution in the forest is irrespective of soils and topography.

\section{RESULTS}

\section{Phytocoenose-diversity and ecological indicatory values}

Twenty-two synuisa have been described: three annual synusia, six low perennial-herbaceous synusia, four high perennial-herbaceous synusia, five shrubby synusia, one liana synusia and three treesynusia. On the basis of their relationships these synusia are gathered into seven phytocoenoses. The ecological indicatory values and of each phytocoenose are presented in table 1. The phytocoenoses identified are mapped on figure 3 .
Variation of plantation productivity within phytocoenoses

To describe the variation of plantation productivity within phytocoenoses, we only consider the phytocoenoses that grow in forest plantations. The variation of plantation productivity within phytocoenoses is presented in table 2. From analysis of productivity indices, we can deduce that:

- the standard deviation of the productivity indices are low (2 $\mathrm{m}$ at most);

- the variation coefficients are also low (7\% at most);

- the amplitude of plantation productivity indices is $4 \mathrm{~m}$ at most and proves that within each non-pioneer phytocoenose, productivity levels belong to the same class of productivity.

From the observations above, we conclude that productivity is remarkably homogeneous within each non-pioneer phytocoenose.

\section{Variation of productivity levels according to phytocoenoses \\ Only the non-pioneer undergrowth} phytocoenoses are taken into account in this analysis. The results of variance analysis are presented in table 3 . The results of the mean comparison test of Newman-Keuls are presented in table 4.

From tables 3 and 4 we deduce that:

- There is a significant difference at $10^{-5}$ probability level between phytocoenose productivity levels ;

- The Mallotus oppositifolius - Deinbollia pinnata phytocoenose is the most productive; its productivity index $(30.4 \mathrm{~m})$ is significantly higher than that of the other phytocoenoses at $5 \%$ of probability level ;

- The productivity level of Paullinia pinnata - Reissantia indica phytocoenose and that of the Uvaria chamae - Macrosphyra longistyla phytocoenose are respectively 27.4 $\mathrm{m}$ and $26.4 \mathrm{~m}$. These two productivity levels are not significantly different at $5 \%$ of probability level. Their productivity level is the intermediate one;

- The Andropogon tectorum - Imperata cylindrica phytocoenose has the lowest productivity level $(16.9 \mathrm{~m})$; its productivity level is significantly different from that of the other phytocoenoses at 5\% of probability level. 


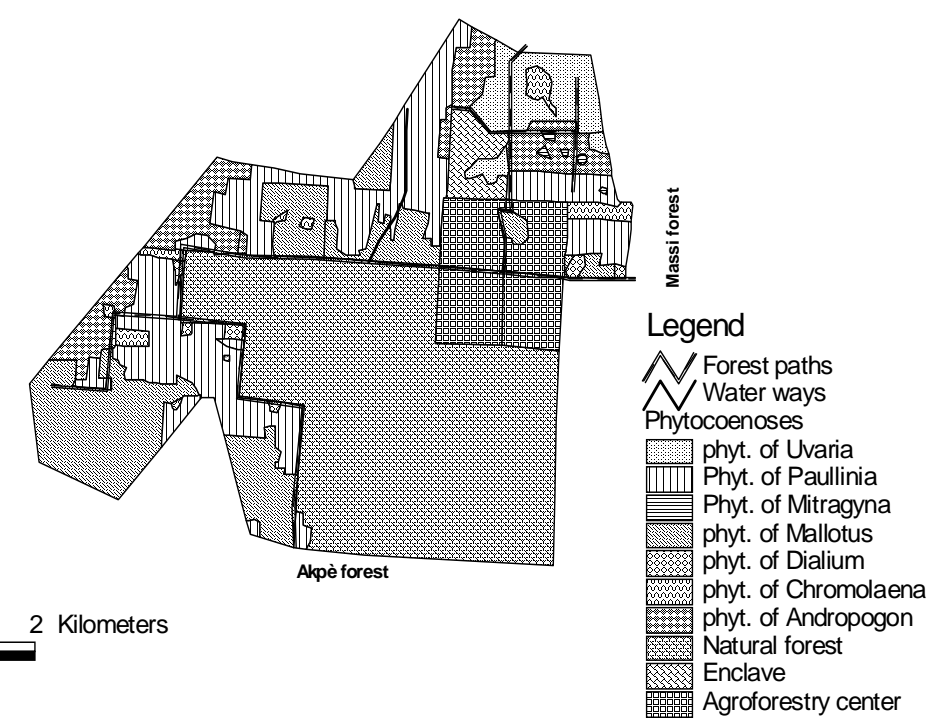

Scale

Figure 2: Phytocoenoses identified in Koto forest reserve. NB: In Figure 2, Phyt. stands for phytocoenose or plant-community.

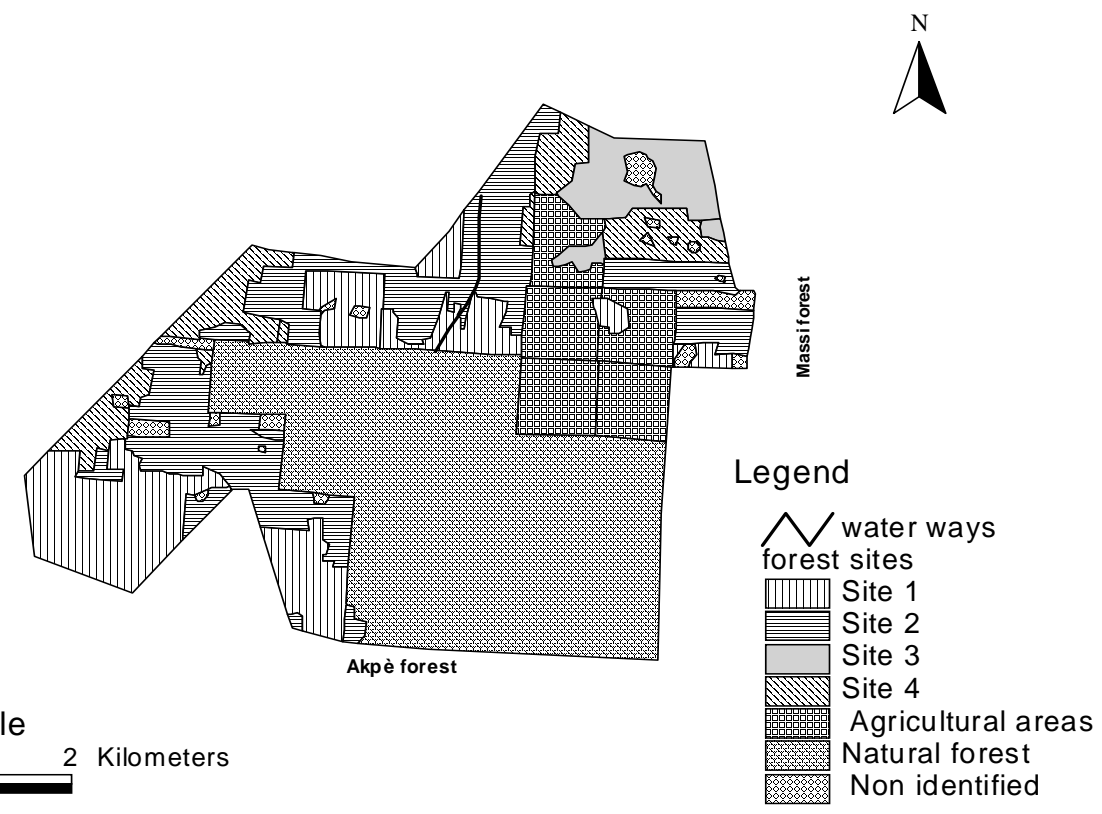

.Figure 3: Forest sites identified in Koto. 


\section{Forest site identification}

From the main conclusions of the previous paragraphs we deduce:

1. non-pioneer phytocoenoses have reliable ecological indicatory values (table 1); we also observe that their biotopes are homogenous in terms of ecological factors (types of soils and topography);

2. plantation productivity within each nonpioneer phytocoenose (table 2) presents very little variation that results in weak values of the standard deviation, variation coefficient and amplitude of productivity indices;

We therefore deduce that the biotopes of each non-pioneer phytocoenose can be considered as forest sites.

Based on productivity levels in phytocoenoses, the forest sites identified in Koto forest reserve are the following (Figure 4):

a. Forest site 1 is the biotope of Mallotus oppositifolius - Deinbollia pinnatacommunity; it is the most productive of Koto forest reserve. Its productivity index values vary from $29 \mathrm{~m}$ to $32 \mathrm{~m}$;

b. Forest site 2 has an intermediate productivity level $(27.40 \mathrm{~m}$ of productivity index). It is characterized by Paullinia pinnata - Reissantia indica phytocoenose;

c. Forest site 3 has an intermediate productivity level (26.38 $\mathrm{m}$ of productivity index). It is characterized by Uvaria chamaeMacrosphyra longistyla phytocoenose;

d. Forest site 4 is the least productive with productivity index values ranging from $15 \mathrm{~m}$ to $18 \mathrm{~m}$ and covers teak plantations of Andropogon tectorum - Imperata cylindrica phytocoenose.

\section{DISCUSSION}

Plant community discrimination

The discrimination of the plant communities identified in Koto forest reserve is the response of the vegetation to ecologic factors. Indeed, pioneer plant community such as Chromolaena odorata-community is only found in part of forest exposed to direct sunlight. The non pioneer plant-communities are found on specific site conditions: Mallotus oppositifolius - Deinbollia pinnata phytocoenose is usually found on well drained black cotton soils; Paullinia pinnata Reissantia indica phytocoenose is confined to ill drained soils of the forest; Andropogon tectorum - Imperata cylindrica phytocoenose grows on degraded soils with low water retention capacity... Our results agree with those of many authors. Indeed, previous phytosociological studies in Benin Republic, confirm the important effects of sunlight, topography and soil types in the differentiation of plant communities (Ganglo et al., 1999; Ganglo, 2005; Noumon and Ganglo, 2005; Aoudji and Ganglo, 2006; Ganglo and De Foucault, 2006). In south east Belgium, many site plant communities have been described (Duvigneaud et al., 1977). The results obtained by these authors who clearly relate the site plant communities to specific ecological factors (mainly topography and soils) support our research results. The same observations are also made by Decocq (2000) who identified in the high Oise valley in Belgium, many synusia and plant communities depending on topographic positions and soil types.

\section{Productivity and forest site identification}

In forestry, there are two ways to estimate forest productivity: the first one is the method of direct estimation of forest productivity based on total volume estimation of the forest or measurements of volume increments; the second method is that of indirect estimation of the productivity which consists of using ecological indices, mainly that of climate, soil, topography and plantcommunity (Rondeux, 1993). The results of our study are an illustration of the method of indirect forest productivity estimation. In that field, we have very few research works. Cajander (1926, In Rondeux, 1993) is among the first researchers to have initiated the approach of forest productivity determination on the basis of plant-communities. Other more recent works undertaken in that field are from Dagnélie (1956; 1957) who studied the productivity of beech in Ardennes (Belgium) and obtained a significant variation of productivity levels according to plantcommunities. In Benin, this approach has never been applied in our forest before. By the end the 1990s, we undertook the study of the plant-communities in Benin forests in order to derive reliable tools for forest management. Indeed, by this approach, we successfully identify, characterize and map forest sites according to their productivity levels (Ganglo, 
2005; Aoudji and Ganglo, 2006; Ganglo and De Foucault, 2006). Our research results in Koto forest reserve support those already obtained in Benin and abroad. The benefit of this approach is very interesting. Indeed, before the innovation supported by our research results, many attempts have been done to identify and map forest sites in Benin, by the classical way that consists of studying geology, soils, topography, microclimate..., vegetation and their relationships in order to derive homogenous forest spaces in term of ecological and biological factors. The enormous costs associated to this classical method of forest site identification and mapping are the chief reasons that preclude their achievement.

\section{Forest management specifications}

According to the potentialities and constraints of the phytocoenoses identified in the forest, we can make the following suggestions:

- Case of Mallotus oppositifolius Deinbollia pinnata-community

It is the most productive phytocoenose where production of high timber value must be considered. Apart from teak which is the main species, silvicultural treatments must favour regeneration and growth of native species usually found in the phytocoenose: Dialium guineense, Ceiba pentandra, Afzelia africana...

- Case of Paullinia pinnata - Reissantia indica-community

The site of this plant community is subjected to ill drainage which frequently causes tree fall as a consequence of Teak roots decay. However, with an intermediate productivity level, the site is suitable for Teak timber production. But, ploughing and ridging are necessary if good results are to be expected. In addition, a moderate period of Teak revolution (30-40 years) must be observed in order to reduce plantations degradation. Diospyros mespiliformis is found as a common indigenous forest species in the site. Silvicultural treatments (reduction of trees density, liana cutting on trees...) can help the regeneration and growth of the species.

- Case of Uvaria chamae - Macrosphyra longistyla-community
This phytocoenose has also an intermediate productivity level. The site is suitable for teak timber production. Silvicultural treatments must also enable natural regeneration and growth of native forest species commonly found in the phytocoenose: Antiaris toxicaria, Ceiba pentandra, Triplochiton scleroxylon, Milicia excelsa...

- Andropogon tectorum - Imperata cylindrica phytocoenose

This phytocoenose has the lowest productivity level. Its biotope is not suitable for Teak timber production. We suggest that it is better using firewood species as Acacia auriculiformis or Cassia siamea as forestation species. Other forest species can also be considered, mainly those naturally found in the phytocoenose: Lonchocarpus sericeus, Pterocarpus erinaceus, Anogeissus leiocarpus and Daniellia oliveri...

- Nauclea latifolia - Mitragyna inermis phytocoenose

This phytocoenose is found in hygrophile site with muddy soils periodically flooded with rain water. We recommend native woody and non-woody species growing such as Berlinia grandiflora, Mitragyna inermis and Pterocarpus santalinoides...

\section{Conclusion}

The study helps to identify and describe twenty-two basic plant -communities named synusia. Based on their relationships, the synusia have been combined to describe seven phytocoenoses (plant-communities). Each non pioneer phytocoenose is an expression of specific ecological conditions. The study of plantation productivity has shown remarkable homogeneity of productivity level within each non pioneer phytocoenose. Analysis of variance reveals a significant difference at $5 \%$ of probability level between the productivity levels of the phytocoenoses. We then deduce and describe forest sites. Forest site 1 is the biotope of Mallotus oppositifolius - Deinbollia pinnatacommunity; it is the most productive of Koto forest reserve. Its productivity index values vary from $29 \mathrm{~m}$ to $32 \mathrm{~m}$; forest site 2 has an intermediate productivity level $(27.40 \mathrm{~m}$ of productivity index). It is characterized by Paullinia pinnata - Reissantia indica phytocoenose; forest site 3 has also an 
intermediate productivity level $(26.38 \mathrm{~m}$ of productivity index). It is characterized by Uvaria chamae - Macrosphyra longistyla phytocoenose; forest site 4 is the least productive with productivity index values ranging from $15 \mathrm{~m}$ to $18 \mathrm{~m}$ and covers Teak plantations of Andropogon tectorum Imperata cylindrica phytocoenose.

\section{AKNOWLEDGEMENTS}

We are grateful to the "Coopération Française" and the Embassy of France in Benin for their financial support that enabled us to carry out this study.

\section{REFERENCES}

Aoudji AKN, Ganglo CJ. 2006. Phytosociologie appliquée à l'aménagement des forêts : cas du périmètre forestier de Pahou (Département de l'Atlantique, Sud-Bénin). Journal de Botanique de la Société Botanique de France, 34(3-5): 89-92.

Braun-Blanquet J. 1932. Plant sociology- The study of plant communities (translated and revised). Fuller GD and Conard HS; $439 \mathrm{p}$.

Duvigneaud P, Kestemont P, Timperman J, Moniquet J-C. 1977. La hêtraie ardennaise à Festuca altissima à Mirwart. Biomasse et productivité primaire. In Productivité Biologique en Belgique. Scope. Travaux de la Section Belge du Programme Biologique International, Duvigneau P, Kestemont P (eds); 617p.

Dagnélie P. 1956. Recherches sur la productivité des hêtraies d'Ardenne en relation avec les types phytosociologiques et les facteurs écologiques. Gembloux: Bull. Inst. Agron. Stat. Rech., 24: 249284; 369-410.

Dagnélie P. 1957. Recherches sur la productivité des hêtraies d'Ardenne en relation avec les types phytosociologiques et les facteurs écologiques. Gembloux: Bull. Inst. Agron. et Stat. Rech., 25: 4494.

Decocq G. 2000. La végétation forestière de la haute vallée de l'Oise (Belgique et France): approche phytosociologique intégrée. Belgian Journal of Botany, 133(1-2): 53-83.
FAO. 2005. Evaluation des Ressources Forestières Mondiales 2005. FAO : Rome, Italie ; 320p.

Ganglo CJ, Lejoly J, Pipar T. 1999. Le teck (Tectona grandis L. f.) au Bénin, gestion et perspectives. Bois et Forêts des tropique., 261(3): 17-27.

Ganglo CJ. 2005. Groupements de sous-bois, identification et caractérisation des stations forestières: cas d'un bois au Bénin. Bois et Forêts des tropiques, 285(3): 35-46.

Ganglo JC, de Foucault B. 2006. Plant communities, forest site identification and classification in Toffo reserve, SouthBenin. Bois et Forêts des Tropiques, 288(2): 25-38.

Ganglo JC, Maître H-F. 2003. Etat de la recherche forestière au Bénin-Bilan et perspectives. Actes du Congrès. C-Des Gens et des Forêts en Harmonie. XIIe Congrès forestier mondial, QUEBEC, CANADA. La Forêt, Source de vie. 21 au 28 septembre 2003; 240-241.

Gillet F. 2000. Phytosociologie Synusiale Intégrée. Guide Méthodologique ( $4^{\mathrm{e}}$ édn, revue et corrigée). Université de Neuchâtel ; 68.

Gillet F, de Foucault B, Julve P. 1991. La phytosociologie synusiale intégrée: objets et concepts. Candollea, 46: 315-340.

Guinochet M. 1955. Logique et Dynamique du Peuplement Végétal. Phytogéographie, Phytosociologie, Biosystématique, Applications agronomiques. Masson \& Cie ; $143 \mathrm{p}$.

Hutchinson J, Dalziel JM. 1954-1972. Flora of west tropical Africa. In Crown Agents for Oversea Governments and Administrations ( 3 volumes, $2^{\text {nd }}$ edn), Keay RWJ, Hepper FN (eds). Millbank: London.

Lebrun J. 1947. La Végétation de la Plaine Alluviale au Sud du Lac Edouard (2 volumes). Publ. IPN. Congo belge; 800 p.

Lebrun JP, Stork AL. 1991-1997. Enumération des Plantes à Fleur d'Afrique Tropicale (Vol. 1, 2, and 3). Conservatoire et Jardin botanique de la ville de Genève.

Noumon JC, Ganglo JC. 2005. Phytosociologie appliquée à l'aménagement des forêts : cas du périmètre forestier de Koto (Département 
du Zou, Centre-Bénin). Acta Botanica Gallica, 152(3): 421-426.

Paradis G, Houngnon P. 1977. La végétation de l'aire classée de la Lama dans la mosaïque forêt-savane du Sud-Bénin (exSud-Dahomey). Bull. Mus. Nat. Hist. nat., Paris, $3^{e}$ sér., 503, Botanique, 34: 168198.

Pignatti S. Oberdorfer E, Schaminee JHJ, Westhoff V. 1995. On the concept of vegetation class in phytosociology. Journal of Vegetation Science, 6: 143152.

Rondeux J. 1993. La Mesure des Arbres et des Peuplements Forestiers. Les presses Agronomiques de Gembloux; 521 p.
Sabatier D. 2006. Evaluation multi-échelles de la diversité spécifique, structurale et fonctionnelle des arbres en forêt guyanaise: prise en compte du substrat géologique, des sols et de la dynamique sylvigénétique. Ecosystèmes tropicaux. Actes du 2ème colloque de restitution du programme de recherche, 7-8 novembre 2006. Ministère de L'Ecologie et du Developpement Durable Ecofor, Paris, 125-133.

Viennot M. 1966. Étude des sols de la dépression de la Lama et de ses bordures. Carte pédologique de reconnaissance au 1/50 000. ORSTOM, Cotonou, p.71. 